The morning sittings on Friday, October 7 , were devoted entirely to tuberculosis in the child and in the schools, and in the afternoon to women's work in connection with tuberculosis. Mrs. Nathan Raw and Dr. J. Walker both took part in the discussion, stating the case for England. Perhaps the most interesting contribution of the afternoon was that made by Dr. Hermann von Schrötter on the action of sunlight and high altitudes, and their relation to the treatment of tuberculosis. It was of all the greater interest to English workers in that he had collaborated with Dr. Barcroft, who had been sent out to do similar work at Teneriffe. Some of his observations on the pigmentation of the skin seemed to bear out Prof. Landouzy's thesis. Dr. Schrötter believes that the pigment is formed by the cell, probably by the nucleus, that it does not come directly from the blood, and that the capacity to form pigment under stimulation gives some information as to the activity and stability of the cells. He also spoke of the effect of light, especially the ultra-violet rays, and high altitudes upon respiration, circulation, and metabolism, and is decidedly of opinion that not only is tuberculosis a disease of obscurity, but that it is a disease of concentration of population.

Saturday morning, October 8, was devoted to the nomination of committees and to the reports brought by the various foreign delegates. From these reports it may be gathered that not only in England, Ireland, and Scotland, but in many Continental countries, especially Sweden, tuberculosis is a gradually diminishing factor in both mortality and morbidity.

The social functions held during the conference were almost as interesting as the scientific sederunts. The receptions given by $M$. Beço, the Governor of Brabant, in the Government buildings of the province, and of the Burgomeister and the Town Council of Brussels in the Hotel de Ville, were as interesting from the associations of the places in which they were held as from the people one met there. The annual dinner was also a great success. and the speaking was of a very high order. Amongst the congratulations and messages sent to the conference was one from King George dated from Balmoral Castle:-_" The Queen joins ine in thanking you and the members for your kind telegram. We earnestly pray that successful results may attend your labours, and that a further stimulus may be given to the great international campaign that is being carried out against this terrible disease. George, R. et I." Telegrams were also received from the Queen of Denmark, from the Kings of Rumania, Sweden, Spain, and Norway, from the Emperor of Germany and from President Taft, all of them expressing similar interest in the work of the conference. It may perhaps be held that no outstanding work was brought forward at the conference, but those who were privileged to take part in it could not but feel that these international conferences serve as admirable "stock-taking", occasions, and, as successes and failures are recorded, of determining, or at any rate of obtaining information as to, the best method of carrying on the campaign against the White Scourge. As they are heid in a different country each year, they also afford opportunities of seeing how the work is being tackled and how far it is succeeding in various parts of the world.

\section{THE INTERNATIONAL SCIENTIFIC CONGRESS AT BUENOS AIRES.}

$\mathrm{NE}$ of the important features of the celebration of the Centenario of the Revolution of May 25, 1810 , was the International Scientific Congress. This congress was held in Buenos bires from July II to 25, 1910, inclusive, under the auspices and direct management of the Argentine Scientific Society.

Great interest was manifested in this, as in other portions of the celebration, by the residents of Argentina. In spite of the distance from the populous northern hemisphere, the congress was well attended, there was great interest manifested in all the sections, and it can well be said that it was successful.

The opening session of the congress took place on the afternoon of July II in the Colón Theatre, the magnificent playhouse of Buenos Aires. The great popular interest was evidenced by the very large and fashionable attendance at these opening exercises. A short address of welcome was pronounced by the Minister of Public Instruction Dr. Rómulo S. Naon. The principal address was made by the president of the congress, Engineer Luis A. Huergo, and short addresses by the foreign delegates, the whole being interspersed with excellent music.

The serious work of the congress began on the following. day, when the various sections met at the principal scientific headquarters of the city. One of the sections held meetings in the library of the patriot Bartolomé Mitre, whose resid. ence is now preserved as a museum by the city.

The work of the congress was divided into eleven principal sections as follows:-Mathematies, physics, and astronomy; chemistry; geology and geography; biology anthropology ; engineering; agriculture; psychology and pedagogy ; jurisprudence and social science; military science; and naval science.

In the limits of a short account such as this it will be entirely impossible to give even the titles of all the papers. presented. It is necessary, therefore, to refer only to those which appear "to be of the greater interest to the general readers of NATURE, at the risk of omitting many of equal or perhaps greater importance.

Several of the delegates delikered public lectures in Buenos Aires and I.a Plata. A special meeting of the delegates from Spanish-speaking countries was held at the rooms of the Argentine Scientific Society to inaugurate a movement " to purify, to enrich, and to unify" the technology of the Spanish language.

\section{Mathematics, Physics, and Astronomy.}

Several interesting papers were presented in the field of pure mathematics, notably those by Volterra upon integral equations and their applications, and by Dr. Franck upon the surface of the second order of Lie and their relations to a point upon any surface whatever. Prof. Torres y Quevedo gave an exposition of the mathematical theory of an electromechanical calculating machine. A paper was sent by Prof. L. A. Bauer giving an account of the work done with the new magnetic survey vessel of the Carnegie Institution of Washington, the Carnegie. This vessel has proven successful beyond expectation.

In the subsection of astronomy, the observatories of Santiago, Chile, the temporary observatory of the Carnegie Institution at San Luis, I.a Plata Observatory, and the Argentine National Observatory at Córdoba were represented. The plans for the new Chilean National Observatory were shown by Dr. Ristenpart, as well as photographs of Halley's comet; two charts of the series being prepared by that Observatory from the Cape Photographic Durchmusterung. Prof. Tucker, in charge of the Carnegie branch observatory at San Luis, read a paper dealing with the fundamental system of star positions, which is being prepared by the department of Meridian Astrometry of that institution under the direction of Prof. Boss. Sunrise and sunset tables to I950 were presented by the La Plata Observatory. Several papers were presented by the Córdoba Observatory dealing with the work in progress there, as well as a series of photographs of Halley's comet which had been obtained there. A proposition was discussed to publish an astronomical ephemeris suitable for the South American countries in place of those now issued by several of the observatories.

\section{Chemistry.}

Among the many important papers presented in this section were contributions to the study of Argentine oil, by Dr. Sabatini ; composition of the alfalfa and other forages grown in Argentina, by Engineers Lavenir and Negri. These investigators demonstrated the superiority of corn grown in the Argentine. Dr. Quiroga presented a new chemical nomenclature of inorganic bodies.

\section{Geology and Geography.}

The principal papers in this section related to the countries of Argentina, Chile, and those adjoining to the east and north. The subject of mines and the laws relating to them, including fuel deposits, occupied a chief place. Ergineer Patron presented a paper on the development of geographic and geodetic work of Chile, Prof. Codazzi one on mining in Colombia, Señor Maurtúa on geographicalt

NO. 2 I 38 , VOL. 84] 
work in Peru. Engineer Machado presented a paper on petroleum in Chile, Engineer Hermitte and Lieut.-Col. Romero on the petroleum formation of Argentina. The topography and mineralogy of the Andes region was treated of in various papers.

The Argentine Meteorological Office presented a large number of interesting papers, chiefly upon the meteorology of Argentina and the southern ocean. The director, Dr. Davis, presented a paper upon the temperature of Argentina as compared with other portions of the globe. A paper by Prof. Clayton dealt with a new method of forecasting which promises to cover periods much longer than is now possible. Profs. Mossman and Solyom presented papers on the effect of the antarctic currents upon the weather of South America, and the cyclones and anti-cyclones of the South American continent, respectively.

Dr. Knoche presented a paper descriptive of the organisation of the meteorological service of Chile, and Dr. Montessus de Ballore a paper on a convention of the seismological services of Chile and Argentina. Dr. Negri read a paper on two seismical laws discovered by himself.

\section{Biology.}

The communications to this section included the following :- The action of the principal alkaloids on protozoas, Prof. Scala; a contribution to the study of some arthropods of Chile-Argentina, Prof. Porter; contribution to the study of sea fishes in Uruguay, Prof. Bouyat; the mosquitoes, gad-flies, and serpents of Argentina, Señor Brethes; the marsupials of Chile, Dr. Wolffsohn; the vegetation of the north-western portion of Argentina,. Dr. Seckt; a reclassification of Argentine vascular plants, Dr. Stuckert.

\section{Anthropology.}

Two papers were presented by Dr. Ameghino relating to three fossil human skeletons found in Arroyo Siasgo and E1 Moro. Other papers discussed different characteristics of the Indians and indigenous inhabitants of certain regions of South America, particularly Argentina, and of means of caring for such peoples and preserving accurate data respecting them. The origin of the American races and the languages of different South American races were subjects of investigation. Of especial interest were the results presented by Prof. Mercante of a comparative study of 1200 of the Argentine youth between the ages of six and twenty years, the sexes being nearly equally divided.

\section{Engineering.}

Many of the papers in this section dealt with architecture, particularly that of the Latin American countries. Notable among these were the papers of Engineer González. Engineer Selva discussed the advisability of houses for workmen and the best forms of such houses. A sentiment was adopted emphasising the absolute necessity of finding a solution for the question of reducing house rent for workmen and employees of modest salary. The same author also discussed the subject of earthquake construction. The subject of reinforced cement construction occupied the attention of one session. Railway and bridge questions occupied another session. The question of irrigation is a very important one in several of the South American republics, particularly Argentina. Conforming to the importance of the subject, two sessions were devoted to the discussion of the laws and systems of irrigation in Argentina, and with various plans for betterments. Rivers and harbours and their various needs received attention in another session, as did various municipal matters relating to sanitation, transportation, and streets, in another. The cngineering section attracted unusual attention.

\section{Agriculture.}

Engineer Juan A. Devoto presented a paper detailing his investigations of the micro-organisms of milk. Dr. Wolffhugel read a paper on the zooparasites of the domestic animals of the Argentine Republic. Recommendations were made to protect the guanaco and vicuña. Great interest was manifested in this section, and a large number of papers were presented dealing with the practical details of this branch of science. One which attracted much attention was on the degeneration of the Malbeck, by Señor Suárez.

No. 2 I 38 , VOL. 84$]$
Psychology and Pedagogy.

In this section Prof. Jakob gave the inaugural address, ciscussing human beings with defective brains. Among the papers were:-Value of psychological statistics in pedagogy, Señor Mercante; necessity of methodical investigation of the child and all abnormal persons, Dr. Piñero; abnormal psychology and education, Prof. Senet; investiga. tions of the nervous system, Dr. Roveda; the measurement of intelligence, Dr. Vidal; experiments upon the sensitiveness of the human skin, Dr. Duceschi.

\section{Resolutions.}

During the congress a large number of resolutions were adopted by the various sections, which at the close were ratified by the entire congress. The substance of some of the most important is given below.

The necessity of solving the problem of reduced rent for the workman and the employee, so that they may live near their work, which is usually in the centre of the city. It may be remarked in passing that this question is especially important in Buenos Aires, where the population is spread over a very large area in one-story houses, instead of the tall structures of Anglo-Saxon cities.

Reiterating the necessity of prosecuting and accelerating the Pan-American railroad according to a fixed plan.

The advisability of studying the causes which hinder the nore general adoption of reinforced concrete constructions

"The strong approval of a project for the formation of a "Union Internacional Hispanoamericana de Bibliografía y 'Tecnología Cientificas." The details of such an organisation were. worked out.

Recognising the convenience of a reform of the Gregorian calendar.

Recognising the advantage of adopting the meridian of Greenwich for all American countries and from January, I9II, basing their time on meridians differing by an exact number of hours from Greenwich, as is already in use in the United States.

The urgent necessity of preventing adulterations and frauds in foods.

Recommending the adoption of standards of purity for the potable water of the Republic (Argentina); the necessity of forming an American society of chemists; the establishment of biological stations with a view to the study of marine life and the development of the fish industry; the advantage of legislation which will encourage the development of the petroleum industry and prevent all monopolies in this industry; the study of the German language in science courses along with French and English; the utility of employing the "altazimetro" invented by Rear-Admiral Mansilla, to facilitate nautical calculations; the stereographic method of locating the stars for nautical purposes, proposed by Captain Ballvé; an international American commission of psychological and pedagogical studies and a children's congress of specialists; the formation of agrarian societies modelled after those of France; the greater use of agricultural machinery, and the teaching of the use of such machines; the study of the conditions and regions suitable for the growth of the sugar beet with the view of extending its production; the development of the cotton-growing industry; uniform regulations in all American countries governing the importation and exportation of animals; legislation looking to the protection of working women before and after childbirth, and making compulsory the providing of time and suitable accommodation by employers for the necessary attention to babes.

C. D. Perrine.

\section{RECENT INVESTIGATIONS ON THE} CULTIVATION OF RUBBER. ${ }^{1}$

FXPERIMENTS on the cultivation and preparation of rubber are being pushed forward at several stations, and the results are discussed in the agricultural journals circulating in tropical and subtropical countries. Methods of tapping the tree have been studied in Hawaii, and found to have a marked effect on the yield of latex. Trees 1 Tropical Life.

The Agricultural News. (Imperial Department of Agriculture for the West Indies.)

Rulletins of the Federated Malay States, and of the Hawaii Agricultural Experiment Stations. 